\title{
PV-T Kollektör kaynaklı bir ısı pompası sisteminin enerji ve ekserji analizi
}

\section{Energy and exergy analysis of a PV-T collector welded heat pump system}

\author{
Mehmet Altınkaynak ${ }^{1, *}$ (D), Recep Demirekin ${ }^{2}$, Ali Kemal Yakut ${ }^{3}[D$ \\ ${ }^{1,3}$ Isparta Uygulamalı Bilimler Üniversitesi, Makine Mühendisliği Bölümü, 32200, Isparta, Turkey \\ ${ }^{2}$ Süleyman Demirel Üniversitesi, Makine Eğitimi Bölümü, 32260, Isparta Türkiye
}

\begin{abstract}
Özet
Günümüzde düşük enerji girdisi ile yüksek 1sıl performansın sağlandiğ 1 1S1 pompası sistemlerinde, sistemin kurulacağı bölge, jeolojik yapı, coğrafi konum ve mevsimsel şartlar dikkate alındığında bu sayılan gerekçeleri karşılamak amaciyla toprak kaynaklı 1s1 pompası, hava kaynaklı 1s1 pompası ve su kaynaklı 1s1 pompası çeşitlerine talep gün geçtikçe artmaktadır. Bu çalışmada toprak kaynaklı 1sı pompasına destek amaçlı 72 hücreli, tek kristal silisyum modül hücre paneline sahip 190W nominal güç üreten bir PV-T kollektör hesaplama için kullanılmıştır. PV-T destekli ısı pompası sistemindeki her bir eleman için enerji ve ekserji analizleri EES (Engineering Equation Solver) programı yardımıyla yapılmıștır. Kullanılan PV-T hibrit sistemde toplam elektriksel güç $1422 \mathrm{~W}$, toplam alınan 1sıl güç te 4397 W'dır. PV-T kollektörün 1sıl verimi \%49.7, elektrik verimi \%15.2 olarak hesaplanmıştır. PV-T kaynaklı 1sı pompası sistemine kollektörlerin verim katkısı \%67,9 olarak görülmüştür. Işınım şiddeti arttıkça toplam elektriksel gücün ve toplam alınan ısıl gücün arttığı görülmüştür. Ayrıca yapılan bu çalışmada 1sı pompası sisteminin COP si 4,41 olarak hesaplanmıştır. En yüksek ekserji yıkımının kondenserde olduğu görülmüştür.
\end{abstract}

Anahtar kelimeler: PV-T, Is1 pompas1, Enerji, Ekserji, COP

\section{Giriş}

Fosil yakıtların çevreyi kirletmesinden dolayı alternatif olarak en ön planda temiz ve yenilenebilir enerji kaynağ olan güneş enerjisi bulunur. Yeryüzünün bir yılda aldığ güneş 1şınım enerjisi, dünyadaki belirlenmiş tüm fosil yakıtın yaklaşık 160 katıdır. Ayrıca güneş; dünyadaki hidroelektrik, nükleer ve fosil yakıtlarla üretilebilecek enerjiden 15 bin kat daha fazla enerjiyi bizim kullanımımıza sunmaktadır. Dünyaya, güneşten saniyede 170 milyon MW enerji gelmektedir [1,2].

Dünya'da güneş enerjisi tek başına 1sı ihtiyacını karşılayamamaktadır. $\mathrm{Bu}$ nedenle bir enerji kaynağına ihtiyaç vardır. İnsanların bu tür gerekli ihtiyaçlarını karşılayabilmek için kullanılan 1sıtma sistemlerinin bir tanesi de $1 \mathrm{~S} 1$ pompalarıdır. Isı pompaları; mekanik enerjiyi 1S1 enerjisine çeviren bir sistemdir.

Elektrikli 1sitma sistemlerine göre 4-5 kat daha iyi sonuçlar vermektedir. Aynı tesisat ile hem 1sitma hem de

\begin{abstract}
Today, demand for soil source heat pump, air source heat pump and water source heat pump types with low energy input and high temperature performance has been increasing considering the region where the system will be built, geological structure, geographical location and seasonal conditions. In this study, a PV-T collector which produces $190 \mathrm{~W}$ rated power with 72 cell single crystal silicon module cell panel has been used for supporting the ground source heat pump. Energy and exergy analyzes for each element in the PV-T assisted heat pump system has been done with the help of EES (Engineering Equation Solver) program. In PV-T hybrid system, total electrical power is $1422 \mathrm{~W}$ and total thermal power is $4397 \mathrm{~W}$. Thermal efficiency of PV-T collector has been calculated as $49.7 \%$ and electrical efficiency as $15.2 \%$. The efficiency contribution of the collectors to the PV-T welded heat pump system has been $67.9 \%$. It has been observed that the total electrical power and the total thermal power increases as the intensity of heat goes up. In this study, the COP of the heat pump system has been calculated as 4.41. The highest exergy destruction has been observed in the condenser
\end{abstract}

Keywords: PV-T, Heat pump, Energy, Exergy, COP

soğutma işlemi yapabilmektedir. Çevreye duyarlı bir sistem oldukları için tercih edilirler [3].

PV / T (fotovoltaik / termal) teknolojisi, güneş enerjisinin daha kapsamlı kullanımını sağlayan, verimliliğini artırabilen ve geniş bir uygulama beklentisine sahip olan PV modülü (fotovoltaik kullanım) ve toplayıcının (foto termal kullanım) bir kombinasyonudur. Literatürde PV panele ve PV-T kollektöre yönelik çok sayıda çalışma yapılmış olup genellikle PV-T kollektörlerin soğutulması amaciyla bu kısım evaporatör olarak dizayn edilmiştir. Yao vd.[4], PV-T kollektörünü evaporatör olarak kullandıkları 1sı pompası siteminde ortam 1sitması yapmak amaciyla faz değiştiren malzemeler ile de enerji depolama ișlemi yapmışlardır. PV$\mathrm{T}$ 1S1 pompas1 sisteminin matematiksel modelini oluşturmuşlardır. $20 \mathrm{~m}^{2} \mathrm{PV}-\mathrm{T}$ panel modülü kullanarak yaptıkları çalışmada $600 \mathrm{~W} / \mathrm{m}^{2}$ güneş 1 şınımı için COP $\% 5.79$, 1s1l verimi $\% 55.76$ ve sistem verimini ise $\% 75.49$ olarak hesaplamışlardır. Özakın vd. [5], PV-T ve 1Sı

\footnotetext{
* Sorumlu yazar / Corresponding author, e-posta / e-mail: mehmetaltinkaynak@ sdu.edu.tr. (M. Altınkaynak)

Geliș / Recieved: 24.02.2020 Kabul / Accepted: 28.01.2021 Yayımlanma / Published: 27.07.2021

doi: 10.28948/ngumuh.693384
} 
pompasını birleştirerek kombine bir sistem oluşturmuşlardır. Çalışmalarında PV-T'yi evaporatör olarak kabul etmişler ve evaporatörün performans katsayısı ve ekserjetik verime olan etkisini fluent yardımıyla incelemişlerdir. Sonuçlara göre elektriksel verimin beklendiği şekilde arttığını görmüşlerdir. Sistemin COP değerinin 4.75 olduğunu, kombine sistemin ekserjetik veriminde soğutucu akışkanın $6 \mathrm{~m} / \mathrm{s}$ akış hızında olduğu durumda \% 55.5 olarak hesaplamışlardır. Ji vd. [6], PV destekli bir 1sı pompası sistemini incelemiş ve yaptıkları deney setinde PV panel üzerine buharlaştırıcı yerleştirerek yeni bir dizayn ile hem elektrik hem de 1sıl enerji alabileceklerini ifade etmişlerdir. Verim olarak kıyaslandığında PV panel verimini \%12, 1sıl verimi ise \%50 civarında bulmuşlardır. Yaptıkları başka bir çalışmada, güneş enerjisi destekli bir 1sı pompası sisteminde güneş enerjisini evaporatör olarak tasarlamışlar ve performans analizlerini incelemişlerdir. Yaptıkları analizlerde COP değerini 8.4 panel verimini ise $\% 13.4$ olarak hesaplamışlardır [7]. Yine yaptıkları diğer bir çalışmalarında, PV-T güneş kollektörünün performans analizini bir yıldan fazla deneysel olarak ölçümlerle incelemişlerdir. PV sistemlere göre PV-T sistemlerinde yüzey sıcaklığının soğutucu akışkan yardımıyla düşürülmesi ile daha verimli olduğunu ifade etmişlerdir. Sonuçlarda ise, PV-T evaporatör sisteminde verimin \%64-87 aralığında olduğunu, 1sıl verimin de \%53-64 ve son olarak da PV kolektörün veriminin \%12.4-14.5 arasında olduğunu deneysel olarak bulmuşlardır [8]. Fu vd. [9], güneş enerjisi destekli bir 1sı pompası sisteminde üç farklı durum için modelleme yaparak analiz yapmışlardır. İlk önce 1sı borusu, ikinci durumda güneş enerji destekli bir 1s1 pompasın1, üçüncü durumda ise hava kaynaklı 1sı pompası sistemini incelemişlerdir. Hong-Kong' da yaptıkları deneylerde enerji tasarrufu sağlamak üzere yeni bir tip üç mod da çalışabilen hibrit bir sistem önermişlerdir. Hibrit sistemin enerji ve ekserji analizlerini yapmışlardır. Daghigh vd. [10], yaptıkları çalışmalarında PV-T kollektörlerdeki 1sınmayı gidermek için su ve soğutucu akışkanlar kullanmayı tercih etmişlerdir. Su soğutmalı ve soğutucu akışkanlı hibrit fotovoltaik termal toplayıcılı sistemlerin gelecekteki durumları üzerine yorumlar yapmışlardır. Bu çalışma ile doğrudan genleşmeli güneş destekli 1sı pompası sistemi ile PV / T toplayıcının soğutma etkisi altında daha iyi sonuçlar elde ettiğini ortaya koymuştur. Tyagi vd. [11], yaptıkları derleme makalede güneş enerjisi sisteminin 30 yılını göz önüne almış ve son 30 yıldan bugüne güneş enerjisi sistemlerinin devamlı bir araştırma ve geliştirmeye sahip olduğunu gözlemlemişlerdir. Verimli güneş enerjisi sistemleri için yeni nesil ekipman ve malzemelerle iyileştirmelerin olduğunu belirtmişlerdir. Tek bir cihazla PV-T kollektörleri ile hem elektrik enerjisi hem de 1 sıl enerji elde edilebileceğini ifade etmişlerdir. Ayrıca bu sistemler ile 1sıtma, sudan tuzun ayrıştırılması, güneş serası, PV-T kollektör destekli 1sı pompası son olarak ta soğutma yapılabileceğinin metotları hakkında bilgi vermişlerdir. Zhang vd. [12], Pekinde müstakil bir evin 1sitılması amacıyla, üç akışkanlı PV- T 1sı pompası hibrit sistemi önermişlerdir. Ayrıca bu sistem için matematiksel bir model de ortaya koymuşlardır. Geleneksel tip hava kaynaklı bir 1s1 pompasina kıyasla, bu sistemde \%13.2'lik br enerji tasarrufu sağladıklarını belirtmiş̧lerdir. Geleneksel bir PV panele göre ise sistemde \% 14.7'lik enerji üretimi sağlamışlardır. Shao vd. [13], bina çatısına yerleştirdikleri PV-T kollektör 1sı pompası sistemimin farklı mevsimsel performanslarını deneysel olarak incelemişlerdir. Yaz aylarında, kış aylarına göre daha iyi performans gösterdiğini ifade etmişlerdir. Deneylerdeki verilerin analizleri sonucunda elektriksel verimi \%11.23, 1 s1l verimi ise $\% 64.25$ olarak hesaplamışlardır. Tüm yıl için ortalama COP değerini 5.9 olarak bulmuşlardır. Zhou vd. [14], Çin'de yaptıkları teorik ve deneysel karşılaştırmalı çalışmada, mini kanallı PV-T kollektör 1sı pompası modelini geliştirmişlerdir. Veriler ile modelleme ve simülasyon tekniklerini uygulayarak ölçüm sonuçları ve teorik sonuçları karşılaştırmışlardır. Karşılaştırma sonucunda hata analizlerinde \%4-9 arasında hata payı olduğunu bununda sebebinin mevsimsel olaylara dayalı olduğunu ifade etmişlerdir. Mini kanallı sistemden sonra yaptıkları bir diğer çalışmada, mikro kanallı PV-T kollektör 1sı pompası modelini geliştirmişlerdir. Teorik ve deneysel karşılaştırmalı çalışmada, veriler ile modelleme ve simülasyon tekniklerini uygulayarak ölçüm sonuçları ve teorik sonuçları karşılaştırmışlardır. Yine yaptıkları hata analizlerinde \% 7.2 arasinda mevsimsel olaylara dayanan sapmaların olduğunu ifade etmişlerdir. PV / T modülünün deneysel ortalama elektrik, termal ve toplam verimliliği sirasıla\%13.1, \%56.6 ve \%69.7'dir. Sistemin ortalama deneysel ve simüle edilmiş COP değeri sırasıyla 4.7 ve 5.0'dır [15]. Ammar vd. [16], yaptıkları çalışmada farklı güneş 1şınımı değerleri için PV-T kollektör destekli 1s1 pompası sisteminin enerji ve ekserji analizlerini EES ve Hottel-Whillier denklem çözücülerini kullanarak hesaplamışlardır. R134a soğutucu akışkanını kullandıkları sistemde PV panel sicaklığının maksimum $35.68{ }^{\circ} \mathrm{C}$, elektriksel verimin $1000 \mathrm{~W} / \mathrm{m}^{2}$ de maksimum seviyede $\% 11.56$ olduğunu ifade etmişlerdir. Ortalama COP değerini 6.14 bulmuşlardır. Bellos ve Tzivanidis [17], yedi farklı akışkanı sabit durumda tamamen PV enerjisi ile çalıştırılan bir 1sı pompası sisteminde incelemişlerdir. Optimum tasarım noktalarında R32 ve ona en yakın performans değerini gösteren R1234yf akışkanı olduğunu belirtmiş̧lerdir. Optimum tasarım koşullarında $10 \mathrm{~m}^{2}$ PV panel ile 1sı pompasını besleyebilmişler ve isıtmada $4.33 \mathrm{~kW}$, elektrik üretiminde $0.53 \mathrm{~kW}$ net elektrik üretmişlerdir. Ayrıca günlük ortalama enerji verimliliğini \%60.53, ekserji verimini ise $\% 9.26$ olarak hesaplamışlardır. Razali vd. [18], yaptıkları çalışmada PV-T kollektörde 0.012-0.255 kg/s debilerinde su akışlı bir sistemin deneysel analizini ele almışlardır. Farklı güneş 1şınım şiddeti değerleri için güç üretimini incelemişlerdir. Ekserji oluşumu değerlerini ise $700 \mathrm{~W} / \mathrm{m}^{2} \mathrm{ve}$ $900 \mathrm{~W} / \mathrm{m}^{2}$ 1şınım şiddetleri için sırasıyla \%22.48 ve \%20.87 bulmuşlardır. Coventry, yapmış olduğu çalışmada, PV-T sistemin çalışma şartlarında ki verilerini göz önüne alarak analizler yapmışlardır. Analiz sonuçlarına bakıldığında, yoğunlaştırılmış $\mathrm{PV} / \mathrm{T}$ modüllerinin 1 sıl verimin $\% 58$ civarında, elektriksel verimin \%11 civarında ve toplam verimin yaklaşık olarak \%69 olduğunu bildirmiştir [19]. Yamaç yapmış olduğu yüksek lisans tezinde, güneş enerjisi destekli bir 1sı pompasını incelemiş, sistemde R-134a akışkanını kullanmıştır. Analizler sonunda işletmenin 
günlük 5 ton suya ihtiyacının olduğunu ve bu suyun sicaklığının yaklaşık $36^{\circ} \mathrm{C}$ 'den isitılarak $50^{\circ} \mathrm{C}$ 'ye çıkartılabilmesi için 1sı pompasının ihtiyacı olan ısı yükünün ne kadarlık kısmının kolektör yardımıyla karşılandığını araştırmış ve sonuç olarak sistemin COP değerini 4.39 olarak bulmuştur [20]. Duran, Isparta ili için PV-T kolektör sistemini yüksek lisans tez çalışmasında deneysel olarak incelemiştir. Elektrik üretimim esnasında meydana gelen panel sıcaklığının artması ile düşen elektrik verimini paneli soğutarak artırmayı amaçlamıştır. PV panelin arka yüzüne yerleştirdiği borularla ile su akışını sağlayarak soğutmayı amaçlamış ve panelin soğuması ile hem fotovoltaik termal (PV-T) sistemin verimini arttırmış hem de sıcak su elde etmiştir. Yürüttüğü çalışmada farklı panel açıları ve farklı soğutma suyu debileri kullanmıştır. Yaptığı çalışmanın sonucuna göre elektrik üretiminde yaklaşık \%35'lik güç artışı ve \%7'lik verim artışı elde etmiş ve ekserji analizi sonucuna göre ekserji verimi ortalamasını \%21 olarak bulmuştur [21]. Fudholi vd. PV modülden imal edilen bir PV-T panelin performansını değerlendirmişlerdir Yaptıkları analiz sonucu $800 \mathrm{~W} / \mathrm{m}^{2} 1$ şınım ve $0.041 \mathrm{~kg} / \mathrm{s}$ su debisinde, $\% 13$ PV verimi ve $\% 52$ ssıl verim elde etmişlerdir. Debinin artması ve azalması panel yüzeyinin soğumasını aynı zamanda sicak suyun üretilmesini de etkilediğini belirtmişlerdir [22]. Benli, aynı koşullarda PV ve PV/T kolektörlerinin performanslarını deneysel olarak karşılaştırmıştır. Akışkan olarak iki sistem içinde su kullanmış ve 1şınım, dış hava sıcaklığı, su giriş sıcaklığı, su debisi gibi farklı parametreler üzerinde çalışma yürütmüştür. Yaptığı çalışmada PV/T kolektörlerinin PV kolektörlere göre elektriksel ve termal verimin yüksek olduğu sonucuna varmıştır [23]. Caner, yatay tip toprak kaynaklı 1sı pompası sistemini Sivas koşulları için incelemiş, yerin $2.5 \mathrm{~m}$ altına 4 hattan oluşan, içinde su- antifriz karışımı bulunan 1sı değiştiricileri kullanarak toplam uzunluğu $370 \mathrm{~m}$ olan sistemi kurmuştur. Çalışmasının sonucunda ısı pompası ve sistemin performans katsayılarını (COPPIP ve COPS) sirasıyla 2.3-1.96 ve 1.99-1.7 değerleri arasında olduğunu bulmuştur [24]. Al-Khaldi, Toprak kaynaklı ısı pompasının 1sıtma performansını Isparta ili şartlarında bir 1sıtma uygulaması üzerine farklı debilerde ve farklı karışım oranlarıyla irdelemiştir. Yaptığı çalışma toprak altı ve toprak üstü olmak üzere iki çevrimden oluşmakta ve en iyi sonuçları \%5 karışım oranı, $21 \mathrm{~L} /$ dak hacimsel debi ile almıştır. Çalışmanın en yüksek COP 3.42 ve sıcaklığı ise $27.2^{\circ} \mathrm{C}$ olarak bulmuştur [25]. Horzum, Antalya'da bir meskende bulunan toprak kaynaklı 1sı pompası sistemine ait verileri termodinamik açıdan yorumlamıştır. Termodinamik analiz sonucunda 1s1 pompasının ikinci yasa verimi ve COP değerleri sirasıyla 0.6649 ve 3.683 olarak bulmuştur [26].

Literatürde de görüldüğü gibi, PV / T sisteminden daha fazla güç ve 1sı elde etmek için PV hücresini soğutmak ve sıcaklığını azaltmak gerekir. Bu durum sonucunda sistemin daha verimli olduğu bilinmektedir. Dolayısıyla yüzeyin soğutulması amacıyla birçok çalışmada, PV-T kollektörü 1sı pompası sisteminin evaporatörü olarak kullanılmıştır.

$\mathrm{Bu}$ çalışmada da bir 1sı pompası sisteminin kompresörünün çalışabilmesi için gerekli olan elektrik enerjisi ile ısı pompasının evaporatör kısmının alabileceği enerji miktarları üzerine bir sistem tasarımı, Isparta ilinin Eğridir ilçesinin güneyinde bulunan 2109 m yükseklikteki Bozburun dağının yamacında bulunan hali hazırdaki bir adet bağ evi için sistem tasarımı yapılmıştır. Tasarımı yapılan güneş enerjisi destekli bir 1s1 pompası sisteminin enerji ve ekserji analizi yapılmıştır. Güneş enerjisi kullanım yöntemlerinden 1S1 pompasının ve bağlı olduğu sistemin elektrik enerjisi ihtiyacı fotovoltaik panellerden karşılanırken, PV-T panellerdeki ısıtma suyunun bir 1S1 pompasına girdi olarak verilmesiyle sistemin mahal için gerekli olan 1sıtma ihtiyacinın da 1S1 pompasından sağlanması planlanmıştır

\section{Materyal ve metot}

$\mathrm{Bu}$ bölümde, termodinamik yasalara bağlı olarak bazı tanımlayıcı açıklamalar PV-T destekli ısı pompası sisteminin analizi için verilmiştir. Sırasıyla kütle, enerji ve ekserji denge denklemlerini kapsayan ilkeler sistemin iyileştirme potansiyelini araştırmak için incelenmiştir [27]. Kütle denge analizi, herhangi bir termodinamik sistemin analizinde kullanılan en temel bir kuraldır. Rejime sahip bir sistem için kütle dengesi aşağıdaki gibi verilebilir.

$$
\sum \dot{m}_{g}=\sum \dot{m}_{c}
$$

Burada "g" giren akımı, "ç" alt indisi çıkan madde akımını göstermektedir. Enerjinin korunumu ilkesi gereğince kinetik ve potansiyel enerjinin ihmal edilmesiyle enerji denge denklemi aşağıdaki şekilde yazılmıştır [28].

$$
\dot{Q}+\sum \dot{m}_{g} h_{g}=\dot{W}_{n e t}+\sum \dot{m}_{c ̧} h_{c}
$$

Ekserji analizi, enerjinin kullanılabilirliğinin bir göstergesidir. Endüstride üretimde 1sıtmada soğutmada vb. endüstriyel uygulamalarda, enerji sistemlerinde sistemin termodinamik analizi için kullanılmaktadır. Bu sistemlere ait genel ekserji dengesi aşağıdaki gibi yazılmaktadır [27].

$$
\sum_{\mathrm{g}} \dot{\mathrm{m}}_{\mathrm{g}} \mathrm{ex}_{\mathrm{g}}+\dot{\mathrm{E}} \mathrm{x}_{\mathrm{Q}}=\sum_{\mathrm{c}} \dot{\mathrm{m}}_{\mathrm{c}} \mathrm{ex}_{\mathrm{c}}+\dot{\mathrm{E}} \mathrm{x}_{\mathrm{W}}+\dot{\mathrm{E}} \mathrm{x}_{\mathrm{Y}}
$$

Burada ekserji transfer hızı, 1sı transfer hızının ekserjisi ve iş ile alakalı ekserji transfer hızıdır. Ekserji yıkımı ile ifade edilmektedir. Prosesin spesifik ekserjisidir. $\mathrm{Bu}$ kavramlar aşağıdaki şekilde ifade edilir;

$$
\begin{gathered}
\dot{\mathrm{Ex}}_{\mathrm{Q}}=\left(1-\frac{\mathrm{T}_{\mathrm{o}}}{\mathrm{T}_{\mathrm{g}}}\right) \dot{\mathrm{Q}}_{\mathrm{g}} \\
\dot{\mathrm{Ex}}_{\mathrm{W}}=\dot{\mathrm{W}} \\
\mathrm{ex}=\mathrm{ex}_{\mathrm{ke}}+\mathrm{ex}_{\mathrm{pe}}+\mathrm{ex}_{\mathrm{ph}}+\mathrm{ex}_{\mathrm{ch}}
\end{gathered}
$$

Burada ex $_{\mathrm{ke}}$ kinetik ekserjiyi, ex $x_{\mathrm{pe}}$ potansiyel ekserjiyi, $\mathrm{ex}_{\mathrm{ph}}$ fiziksel ekserjiyi ve $\mathrm{ex}_{\mathrm{ch}}$ da kimyasal ekserjiyi ifade etmektedir. Kinetik ve potansiyel ekserjiler ihmal edilebilir olduğundan, fiziksel ekserji aşağıdaki gibi yazılabilir;

$$
\operatorname{ex}_{\mathrm{ph}, \mathrm{i}}=\left(\mathrm{h}_{\mathrm{i}}-\mathrm{h}_{\mathrm{o}}\right)-\mathrm{T}_{\mathrm{o}}\left(\mathrm{s}_{\mathrm{i}}-\mathrm{s}_{\mathrm{o}}\right)
$$


Kimyasal ekserji ise maddenin kimyasal dengesinden kimyasal yapısının uzaklığı ile bağlantılıdır. Yakıtların spesifik kimyasal ekserjileri molar kimyasal ekserji $\left(\xi_{\mathrm{i}}\right)$ ve ilgili yakıtın alt 1 sıl değeri $\left(\mathrm{LHV}_{\mathrm{y}}\right)$ kullanılarak tanımlanır [29]

$$
\dot{E} x_{k m}^{y}=\xi_{i} L H V_{y}
$$

İdeal gazların kimyasal ekserji içerikleri şu şekildedir;

$$
\mathrm{ex}_{\mathrm{ch}}=\mathrm{ex}_{\mathrm{ch}}^{\mathrm{o}}+\mathrm{R}_{\mathrm{u}} \mathrm{T}_{\mathrm{o}} \ln \mathrm{z}_{\mathrm{i}}
$$

Burada $z_{i}$ i numaralı bileşenin mol kesrini ve $\mathrm{ex}_{\mathrm{ch}}^{\mathrm{o}}$ verilen referans sicaklık ve basınçta molar kimyasal ekserjidir ve şu şekilde ifade edilir;

$$
e_{c h}^{o}=\frac{T_{o}}{T} e x_{o, i}^{c h}-\bar{h}_{f}^{o} \frac{T-T_{o}}{T}
$$

Burada ex $\mathrm{o}_{\mathrm{i}}^{\mathrm{ch}}, \overline{\mathrm{h}}_{\mathrm{f}}^{\mathrm{o}}$ ve T sirasiyla “i” numaralı kimyasal bileşenin standart molar kimyasal ekserjisi, oluşum entalpisi ve gazlaştırma sıcaklığıdır. Materyal akışının ekserjisi aşağıda verildiği gibidir;

$$
\dot{\mathrm{E}} \mathrm{x}_{\mathrm{i}}=\dot{\mathrm{mex}}_{\mathrm{i}}
$$

PV-T kollektörün enerjisi aşağıdaki gibi yazılabilir.

$$
\begin{gathered}
Q_{u, P V-T}=A_{c} F_{R}\left[(\tau \alpha) I_{s}-U_{L}\left(T_{i}-T_{a}\right)\right] \\
F_{R}=\frac{\dot{m} C_{p}}{A_{c} U_{L}}\left[1-\exp \left(-\frac{A_{C} U_{L} F^{\prime}}{\dot{m} C_{P}}\right)\right]
\end{gathered}
$$

Burada F' kollektör verim faktörü olup aşağıdaki gibi yazilabilir [30].

$$
F^{\prime}=\frac{1 / U_{L}}{W\left[\frac{1}{U_{L}[D+(W-D) F]}+\frac{1}{C_{b}}+\frac{1}{\pi D h_{f}}\right]}
$$

Burada W 1sı taşıyıcı akışkanın geçtiği boruların arasındaki boşluk (m), D borunun iç çapı (m), F standart kanat verimi, $\mathrm{C}_{\mathrm{b}}$ sınır ve iletkenliği $\mathrm{h}_{\mathrm{f}}$ boruların içindeki 1sı transfer katsayısını ifade etmektedir.

PV-T kollektörlerin enerji verimliliği aşağıdaki gibi verilir [31].

$$
\eta_{P V-T}=\frac{Q_{u, P V-T}}{I_{s} x A_{c}}=\frac{F_{R}\left[(\tau \alpha) I_{s}-U_{L}\left(T_{i}-T_{a}\right)\right]}{I_{s}}
$$

PV-T sisteminin 1sı ekserjisi aşağıdaki gibi ifade edilebilir.

$$
E x_{P V-T, \text { termal }}=\left(1-\frac{T_{i}}{T_{a}}\right) Q_{u, P V-T}
$$

PV-T kollektörler aynı zamanda elektrik enerjisi ve gövdeden 1sı enerji sağladığı için ekserji verimi aşağıdaki gibi yazilır.

$$
\Psi_{P V-T}=\frac{E x_{P V-T}}{E x_{\text {güneş }}}=\frac{V_{m} I_{m}+\left(1-\frac{T_{a}}{T_{i}}\right) Q_{u, P V-T}}{\left(1-\frac{T_{a}}{T_{s}}\right) A_{c} I_{s}}
$$

PV-T kollektör destekli 1sı pompasına ait sistemin akış diyagramı Şekil 1. 'de verilmiştir. Şekilde görüldüğü gibi PV-T kollektör yüzeyinden geçirilen kapalı devre kollektör suyu, kolektör pompası ile PV-T kollektöre basılır. Buradan 1S1 alan su, 1S1 pompasının evaporatörüne gelir. Burada soğutucu akışkana, 1sı değiştirici vasıtasıyla 1sısını bırakır. Isısını bırakan akışkan su tekrar 1sı almak için kollektöre gönderilir. Isı alan soğutucu akışkan buharlaşır ve kompresör ekipmanı ile kondensere basılır. Kondenserde 1sısını radyatör 1sıtma suyuna aktaran soğutucu akışkan, genleşme valfine gelerek soğutma çevrimini tamamlamış olur. Radyatör sistemine ait olan sirkülasyon pompası ile mahal 1sitma suyu kondensere basilarak burada 1s1 yüklemesi yapılır. Aldığı enerjiyi panel radyatör yoluyla ortama aktararak, ortamın 1sıtılması sağlanmış olur.

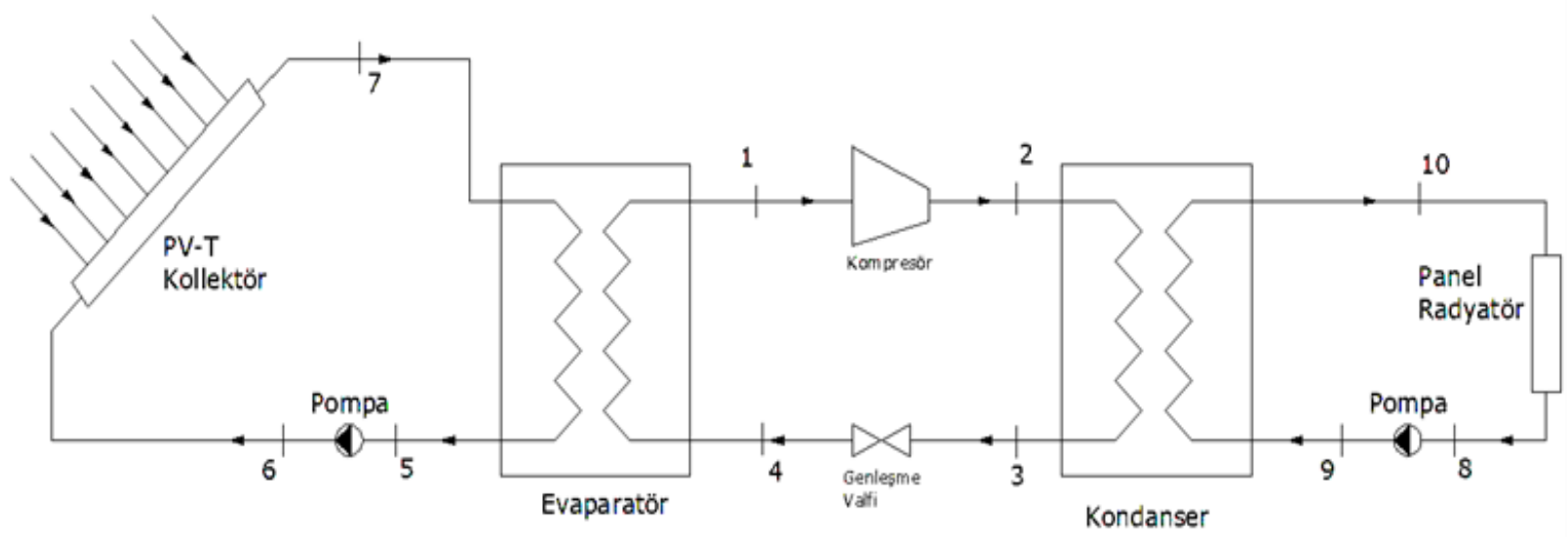

Şekil 1. Sisteminin şematik gösterimi 
PV-T kaynaklı 1sı pompası sisteminin tüm bileşenlerinin kütle, enerji, entropi ve ekserji dengeleri ayrı ayrı parçalanmış olarak aşağıda verilmiştir

Sisteme ait ekipmanlardan PV-T kollektöre ait Şekil 2'de ve kütle, enerji, entropi, ekserji balansları aşağıda verilmiştir.

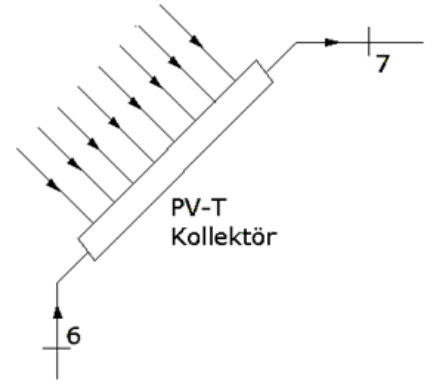

Şekil 2. Kollektör

$$
\begin{array}{lc}
\text { Kütle } & \dot{m}_{2}+\dot{m}_{9}=\dot{m}_{3}+\dot{m}_{10} \\
\text { Enerji } & \dot{m}_{2} h_{2}+\dot{m}_{9} h_{9}=\dot{m}_{3} h_{3}+\dot{m}_{10} h_{10} \\
\text { Entropi } & \dot{m}_{2} s_{2}+\dot{m}_{9} s_{9}+\dot{S}_{\text {üretim,Kond }} \\
& =\dot{m}_{3} s_{3}+\dot{m}_{10} s_{10} \\
\text { Ekserji } & \dot{m}_{2} \text { ex } x_{2}+\dot{m}_{9} \text { ex }
\end{array}
$$

Sisteme ait ekipmanlardan PV-T kollektör ait pompa Şekil 3'de ve kütle, enerji, entropi, ekserji balansları aşağıda verilmiştir.

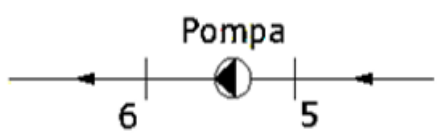

Şekil 3. Kollektöre ait pompa

$$
\begin{array}{lc}
\text { Kütle } & \dot{m}_{5}=\dot{m}_{6} \\
\text { Enerji } & \dot{m}_{5} h_{5}+\dot{W}_{P V-T, p o m p a}=\dot{m}_{6} h_{6} \\
\text { Entropi } & \dot{m}_{5} s_{5}+\dot{S}_{\text {üretim,PV-T,pompa }}=\dot{m}_{6} s_{6} \\
\text { Ekserji } & \dot{m}_{5} \text { ex } \dot{X}_{5}+\dot{W}_{P V-T, p o m p a} \\
& =\dot{m}_{6} \text { ex } x_{6}+\dot{E} x_{y \imath \text { kım }, P V-T, p o m p a}
\end{array}
$$

Sisteme ait ekipmanlardan evaporatör Şekil 4'de ve kütle, enerji, entropi, ekserji balansları aşağıda verilmiştir.

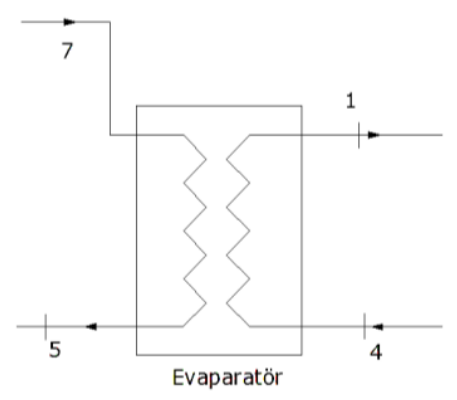

Şekil 4. Evaporatör

$$
\begin{array}{lc}
\text { Kütle } & \dot{m}_{2}+\dot{m}_{9}=\dot{m}_{3}+\dot{m}_{10} \\
\text { Enerji } & \dot{m}_{2} h_{2}+\dot{m}_{9} h_{9}=\dot{m}_{3} h_{3}+\dot{m}_{10} h_{10} \\
\text { Entropi } & \dot{m}_{2} s_{2}+\dot{m}_{9} S_{9}+\dot{S}_{\text {üretim, Kond }} \\
& =\dot{m}_{3} s_{3}+\dot{m}_{10} s_{10} \\
\text { Ekserji } & \dot{m}_{2} \text { ex }_{2}+\dot{m}_{9} \text { ex } \\
& =\dot{m}_{3} \text { ex } x_{3}+\dot{m}_{10} \text { ex } x_{10}+\text { Ex } x_{\text {ylklm,Kond }}
\end{array}
$$

Sisteme ait ekipmanlardan genleşme valfi Şekil 5'de ve kütle, enerji, entropi, ekserji balansları aşağıda verilmiştir.

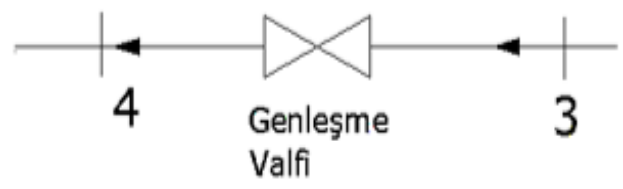

Şekil 5. Genleşme valfi

Kütle

Enerji

Entropi

Ekserji

$$
\begin{gathered}
\dot{m}_{3}=\dot{m}_{4} \\
\dot{m}_{3} h_{3}=\dot{m}_{4} h_{4} \\
\dot{m}_{3} s_{3}+\dot{S}_{\ddot{u} r e t i m, G V}=\dot{m}_{7} s_{7} \\
\dot{m}_{3} e x_{3}=\dot{m}_{4} e x_{4}+E x_{y l k l m, G V}
\end{gathered}
$$

Sisteme ait ekipmanlardan kompresör Şekil 6'de ve kütle, enerji, entropi, ekserji balansları aşağıda verilmiştir.

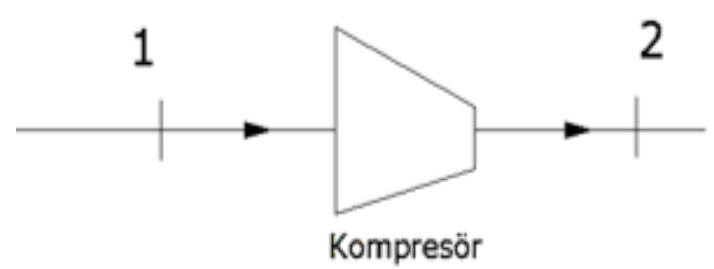

Şekil 6. Kompresör

$$
\begin{array}{lc}
\text { Kütle } & \dot{m}_{1}=\dot{m}_{2} \\
\text { Enerji } & \dot{m}_{1} h_{1}+\dot{W}_{\text {Komp }}=\dot{m}_{2} h_{2} \\
\text { Entropi } & \dot{m}_{1} s_{1}+\dot{S}_{\text {üretim,Komp }}=\dot{m}_{2} s_{2} \\
\text { Ekserji } & \dot{m}_{1} \text { ex } x_{1}+\dot{W}_{\text {Komp }}=\dot{m}_{2} \text { ex } \\
& \\
&
\end{array}
$$

Sisteme ait ekipmanlardan kondenser Şekil 7'de ve kütle, enerji, entropi, ekserji balansları aşağıda verilmiştir.

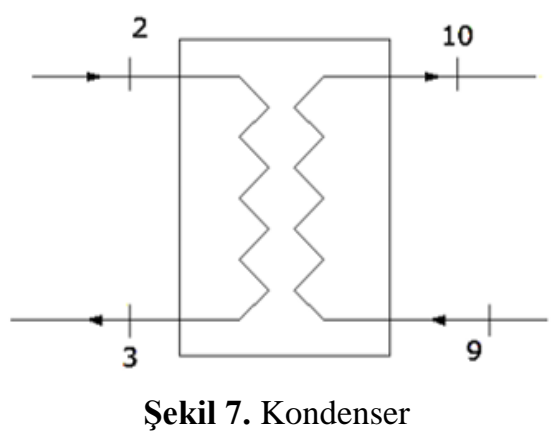


Kütle

Enerji

Entropi

$$
\begin{gathered}
\dot{m}_{2}+\dot{m}_{9}=\dot{m}_{3}+\dot{m}_{10} \\
\dot{m}_{2} h_{2}+\dot{m}_{9} h_{9}=\dot{m}_{3} h_{3}+\dot{m}_{10} h_{10} \\
\dot{m}_{2} s_{2}+\dot{m}_{9} s_{9}+\dot{S}_{\text {üretim, Kond }} \\
=\dot{m}_{3} s_{3}+\dot{m}_{10} s_{10} \\
\dot{m}_{2} \text { ex }_{2}+\dot{m}_{9} S_{9} \\
=\dot{m}_{3} \text { ex } x_{3}+\dot{m}_{10} h_{10}+\dot{E} x_{\text {ylkum }, \text { Kond }}
\end{gathered}
$$

Ekserji

Sisteme ait ekipmanlardan sirkülasyon pompası Şekil 8 'de ve kütle, enerji, entropi, ekserji balansları aşağıda verilmiştir.

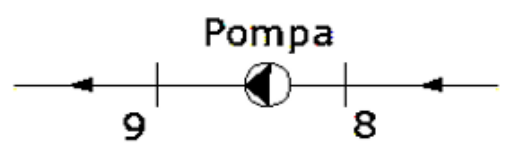

Şekil 8. Sirkülasyon pompası

Kütle

Enerji

$$
\begin{gathered}
\dot{m}_{8}=\dot{m}_{9} \\
\dot{m}_{8} h_{8}+\dot{W}_{\text {pompa }}=\dot{m}_{9} h_{9}
\end{gathered}
$$

Entropi $\quad \dot{m}_{8} s_{8}+\dot{S}_{\text {üretim,pompa }}=\dot{m}_{9} s_{9}$

Ekserji $\dot{m}_{8} e x_{8}+\dot{W}_{\text {pompa }}=\dot{m}_{9} e x_{9}+\dot{E x}_{\text {yıkım,pompa }}$

\section{Bulgular ve tartışma}

PV-T destekli 1s1 pompasında kullanılan R22 akışkanına ait P-h diyagramı Şekil 9' da verilmiștir

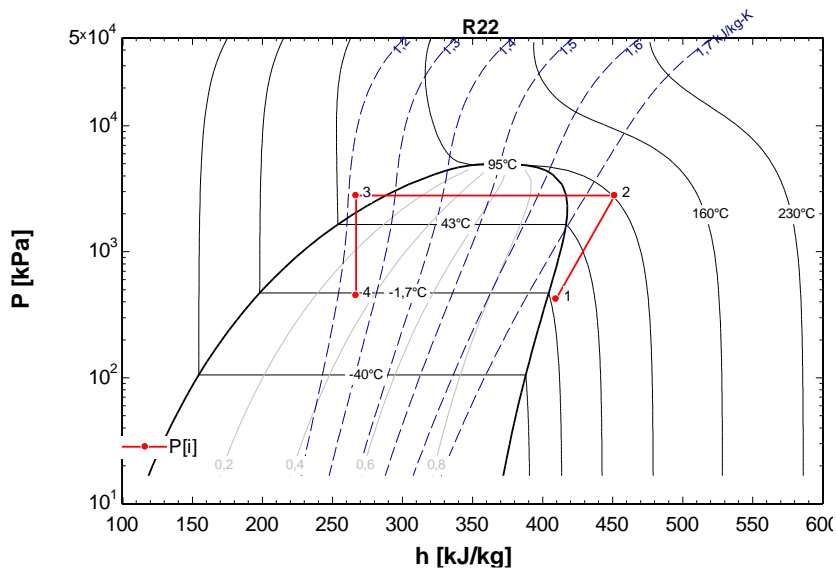

Şekil 9. R22 Soğutucu akışkanı P-h diyagramı

Isı pompasının evaparator çıkış sıcaklığının değişimine bağlı olan COP ve I. Yasa verimi Şekil 10' da verilmiştir. Sistemin COP değerinin akışkanın evaparatör sıcqklığına bağlı olarak değişim aralığı çok kısa olmaktadır. Bunun sebebi evaparatör sıcaklığı aralığının $5{ }^{\circ} \mathrm{C}$ ile $9{ }^{\circ} \mathrm{C}$ arasında tutulmasından kaynaklanmaktadır.

Şekil 10’ de görüldüğü gibi evaporatör çıkış sıcaklığı arttıkça 1sı pompasının COP' si artmakta, dolayısıyla sistemin I. Yasa verimi de artmaktadır. Evaporatör çıkış sıcaklığına bağlı olarak değişimin sistemin COP' sine ve II. Yasa verimine etkisi Şekil 11' de aşağıda verilmiştir.

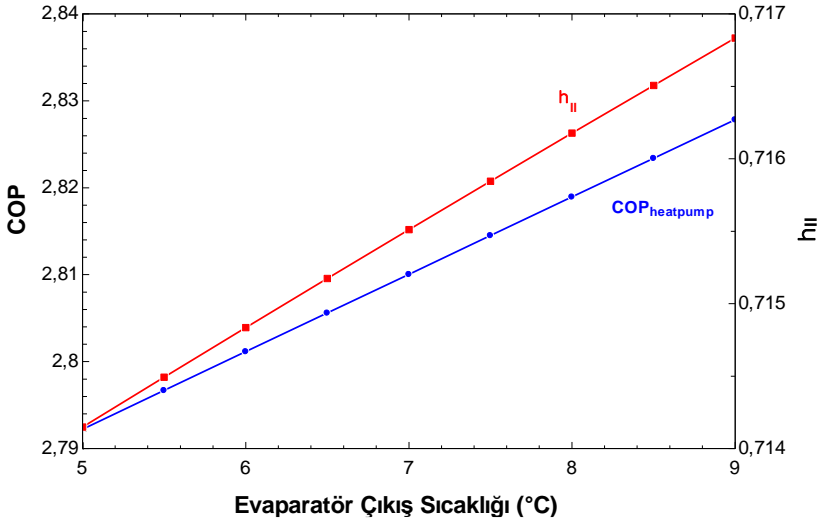

Şekil 10. Evaporatör çıkış sıcaklığına bağlı COP değişimi

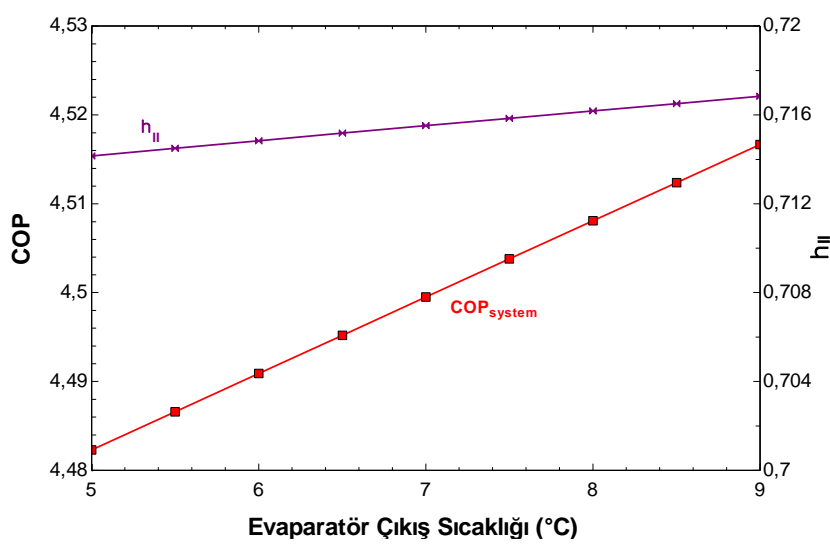

Şekil 11. Evaporatör çıkış sıcaklığına bağlı sistem COP ve II. yasa verimi

Şekil 11' de görüldüğü gibi evaporatör çıkış sıcaklığının artması sistemin COP' sini arttırmış ve doğal olarak bu artış sistemin ekserji veriminin de artmasına sebep olmuştur. Doğal olarak sistemin COP'si 1sı pompasının COP'sinden büyük olmaktadır. Yapılan çoğu çalışmalarda sistem COP değerleri 3.5-5 aralığında çıktığı literatürde de görülmektedir.

Isı pompasının evaporatörünün çıkış sıcaklığının değişiminin sistemin ve isı pompasının COP değişimine etkisi Şekil 12' de verilmiştir.

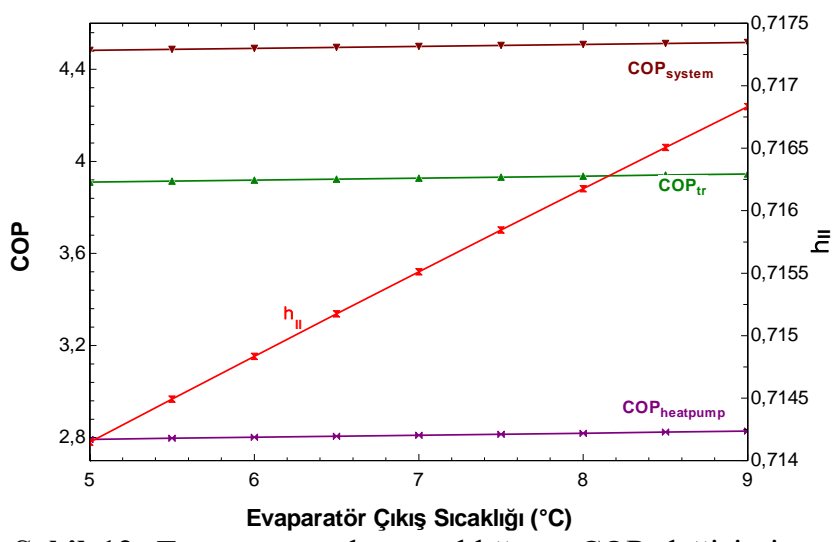

Şekil 12. Evaporatör çıkış sıcaklığının COP değişimine etkisi 
Evaporatörün çıkış sıcaklığının artması sistemin I. Yasa verimini görülür bir düzeyde arttırırken sistemin COP' sini, 1S1 pompasının COP' sini ve $\mathrm{COP}_{\text {tr }}$ değerlerini çok az miktarda arttırdığı Şekil 12' de görülmektedir. Kompresör basıncı değişiminin ekserji yıkımı ve ekserji verimine etkisi Şekil 13'de verilmiştir.

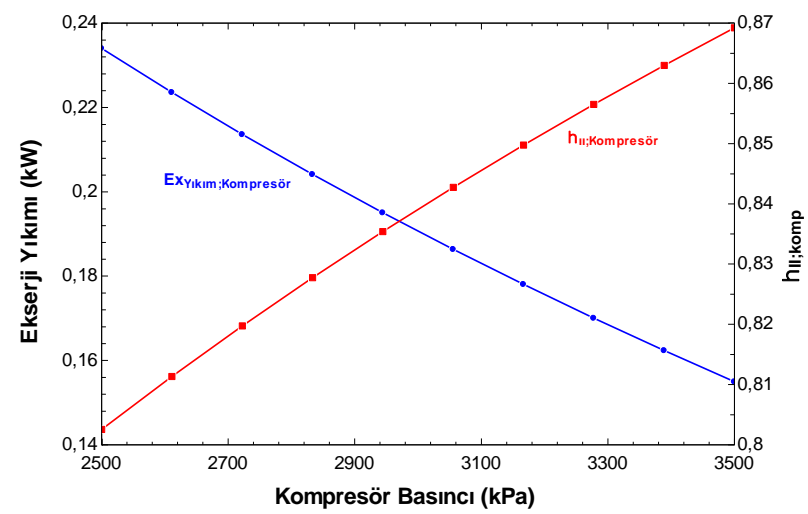

Şekil 13. Kompresör basıncı değişiminin ekserji yıkımı ve ekserji verimine etkisi

$2500 \mathrm{kPa}$ ile $3500 \mathrm{kPa}$ aralığında değişen kompresör basıncının artması kompresördeki ekserji yıkımının azalmasına dolayısıyla II. Yasa veriminin diğer bir değişle ekserji veriminin artmasına sebep olmaktadır. Bu ekserji yıkımındaki azalma değeri $0.227 \mathrm{~kW}$ 'dan $0.148 \mathrm{~kW}$ kadar düşmektedir. Evaporatör çıkış basıncının ekserji yıkımına ve ekserji verimine etkisi Şekil 14' de verilmiştir.

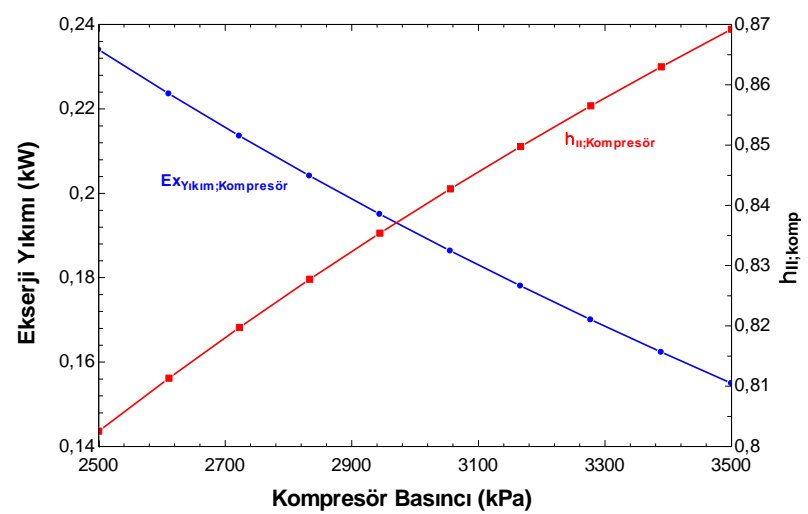

Şekil 15. Evaporatör çıkış basıncının ekserji yıkımına ve ekserji verimine etkisi

Isı pompasının evaporatör çıkış basıncının arttırılması evaporatörün ekserji yıkımını azaltırken II. Yasa verimini arttırdığı Şekil 15' de görülmektedir. Evaporatör çıkış basıncının $500 \mathrm{kPa}$ ile $550 \mathrm{kPa}$ arasında değişimi, evaporatörün ekserji veriminin $\% 87.8$ 'den $\%$ 91.7' ye artmasına sebep olmuştur.

Kompresör basıncı değişiminin kondenser ekserji yıkımına ve verimine etkisi Şekil $15^{`}$ de verilmiştir. Şekilde görüldüğü gibi kompresör basınc1 $2500 \mathrm{kPa}$ dan $3500 \mathrm{kPa}$ çıkartıldığında, kondenserin ekserji yıkımı \% 83.2'den \% 87.9'a artığı görülmüştür

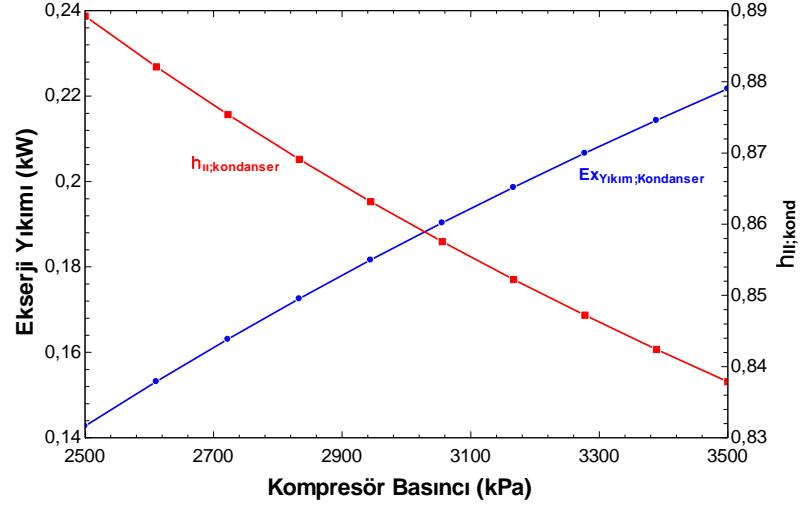

Şekil 16. Kompresör basıncı değişiminin kondenser ekserji yıkımına ve verimine etkisi

Şekil 16'de görüldüğü gibi 1sı pompasının kompresör basıncının arttırılması kondenserdeki ekserji yıkımını arttırmakta ve kondenserin ekserji verimini azaltmaktadır.

Kompresör basıncı değişiminin kondenserin ekserji yıkımına, ekserji verimine ve kondenserden atılan 1S1 miktarına etkisi Şekil. 17' de verilmiştir

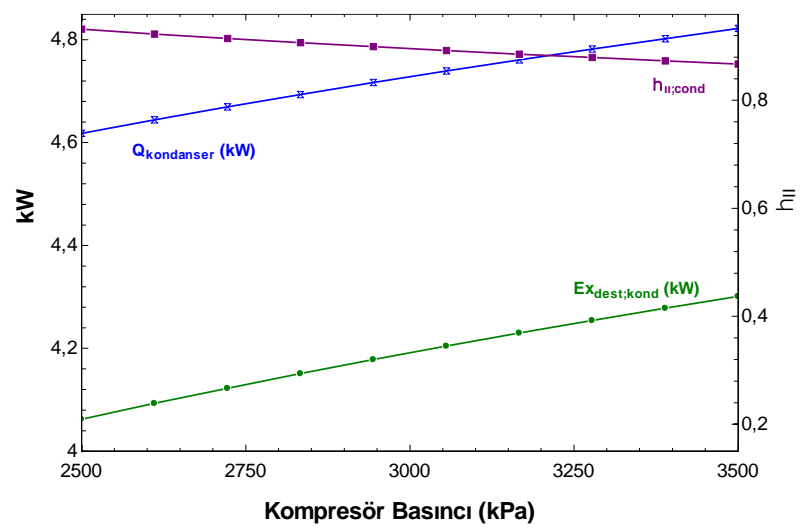

Şekil 17. Kompresör basıncı değişiminin kondenserin ekserji yıkımına ve verimine etkisi

Şekil 17' de görüldüğü gibi 1s1 pompasının kompresördeki basıncının arttırılması kondenserden atılan 1S1 enerjisi miktarını arttırırken aynı zamanda kondenserin ekserji yıkımını da arttırmaktadır. Bundan dolayı ekserji yıkımının artması ekserji verimini azaltacağından kondenserdeki ekserji verimi de kompresör basıncının artmasıyla azalmıştır.

Kompresör basıncının değişiminin 1s1 pompasının COP'sine etkisi ve kompresörün çektiği güce etkisi Şekil 18' de aşağıdaki gibi verilmiştir.

Şekil 18' de 1S1 pompasının kompresör basıncının arttırılması için daha fazla iş verilmesi gerektiği görülmektedir. Ayrıca yine Şekil 18' de 1sı pompasının COP değişiminin kompresör basıncının artmasıyla azaldığ görülmektedir. Şekilde de görüldüğü gibi kompresör basıncının $2500 \mathrm{kPa}$ ile $3500 \mathrm{kPa}$ arasında değişiminin, 1S1 pompasının kompresörünün çektiği elektrik enerjisine 0.5 kW daha fazla yük çekmesine sebep olmuştur. 


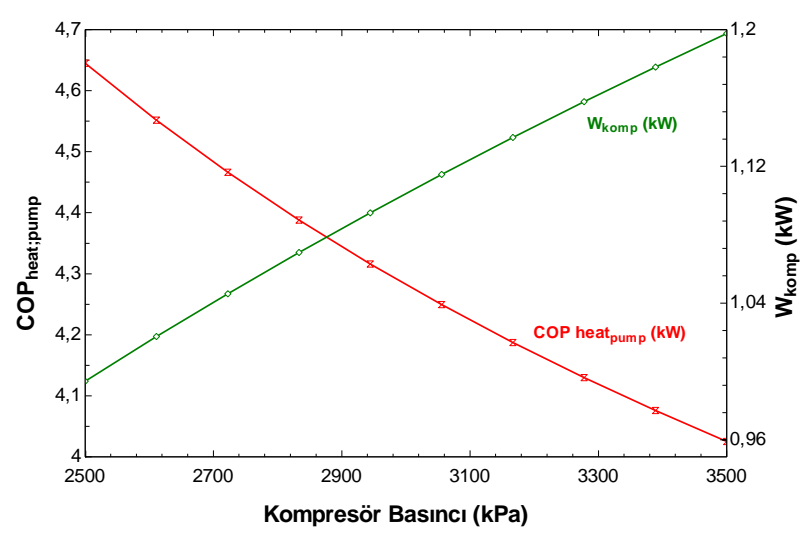

Şekil 18. Kompresör basıncının değiş̧iminin COP ve harcanan işe etkisi

Isı pompası sisteminin çalıştığı dış ortam sıcaklığının değişiminin sistemin COP'sine etkisi ve kompresörün çalıştırılması için verilmesi gereken işe etkisi Şekil 19' da verilmiştir.

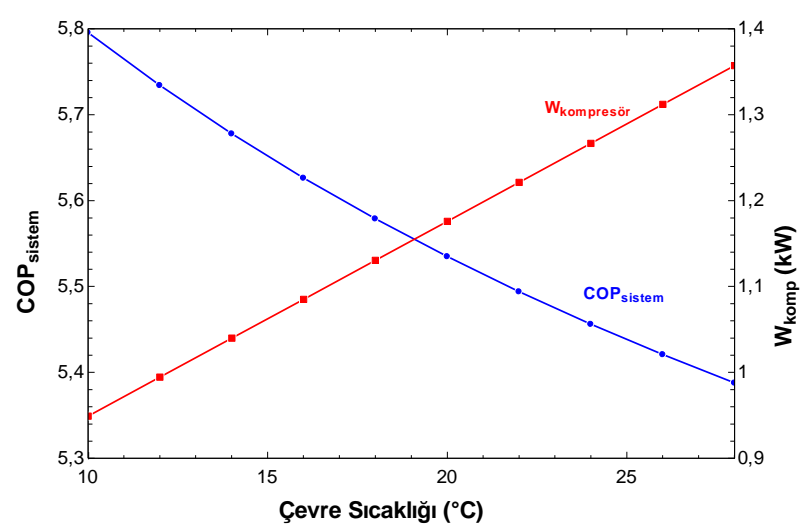

Şekil 19. Çevre sıcaklığının COP ve kompresör işine etkisi

Şekil 19' da görüldüğü gibi çevre sıcaklığının artması sistemin COP değerinin azalmasına sebep olmaktadır. Çevre sıcaklığının artması kompresör emişindeki havanın enerjisini arttıracağından dolayı aynı şartlarda çalıştırılan havanın kompresörde sıkıştırılması zorlaşacağından Şekil 19' da görüldüğü gibi hava sıcaklığının artması kompresörde harcanan işin artacağını ifade etmektedir. Çevre sıcaklığının arttırılması, sistemin COP değerinin $5.8^{\prime}$ den $5.35^{\prime} \mathrm{e}$ düşmesine sebep olmuştur.

Diş ortam sıcaklığının artması PV-T' den gelen isıl enerjinin artmasına ve bu isının 1sı pompasına aktarıldıktan sonra kondenserden atılmasının, çevre havası sıcaklığına bağlı değişim grafiği Şekil 21.' de verilmiştir.

Şekil 20' de görüldüğü gibi çevre sıcaklığının artması PV-T' den gelen 1S1 enerjisinin artmasına sebep olduğu görülmektedir. Isı pompasına destek olarak sağlanan bu PV$\mathrm{T}$ kollektöründen gelen 1s1 enerjisi kondenserden atılacağ1 için doğal olarak kondenser de 1sı enerjisinde artışa sebep olacaktır. Çevre sıcaklığının artması kondenserden atılan 1sınında artmasına sebep olmaktadır.

Dış ortam sıcaklığının artması PV-T arka yüzeyinde ve PV-T içerisinde dolaştırılan, 1sı pompası kaynağına destek amaçlı kullanılan dolaşım suyunun sıcaklığını arttıracağından dolayı PV-T deki ekserji yıkımı artmaktadır. $\mathrm{Bu}$ artış Şekil 21' de görülmektedir.

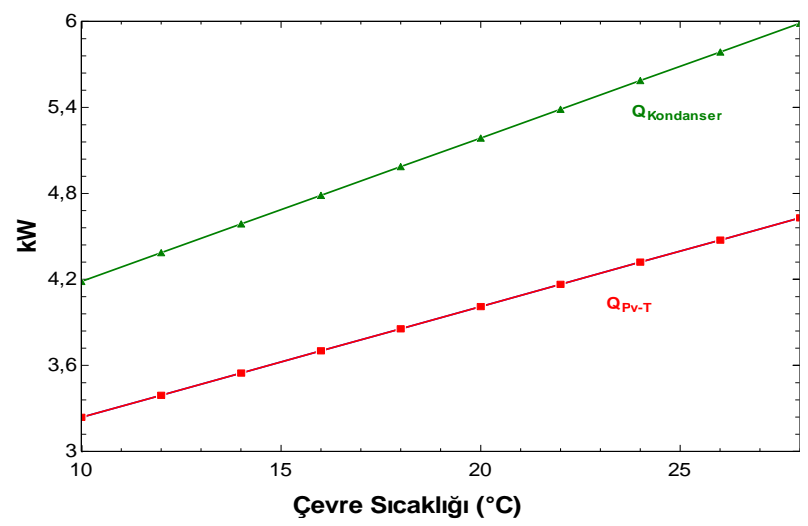

Şekil 20. Çevre sıcaklığının PV-T ve kondenser enerjisine etkisi

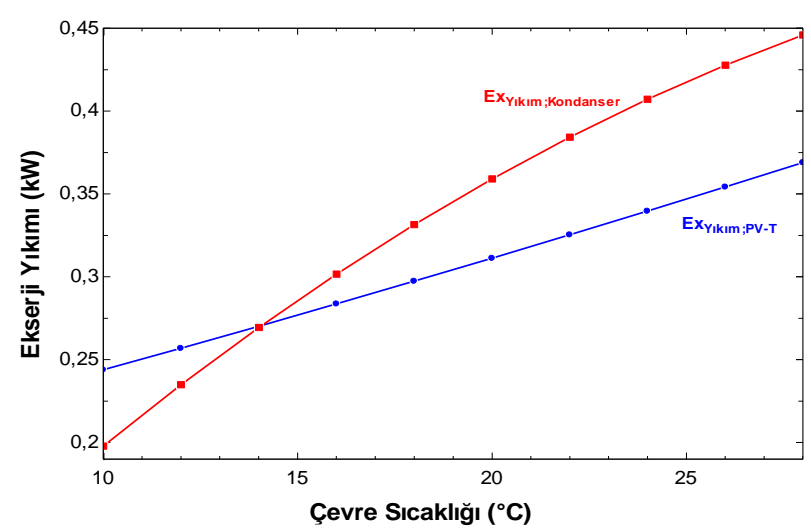

Şekil 21. Çevre sıcaklığının kondenser ve PV-T' nin ekserji yıkımına etkisi

Şekil 21' de görüldüğü gibi çevre sıcaklığının artması kondensere gelen ısıl yükü arttıracağından dolayı, çevre sıcaklığının artması kondenserin ekserji yıkımının artışına da sebep olacaktır.

\section{Sonuçlar}

$\mathrm{Bu}$ çalışmada toprak kaynaklı 1sı pompasına destek amaçlı 72 hücreli, tek kristal silisyum modül hücre paneline sahip 190W nominal güç üreten bir PV-T kollektör hesaplama için kullanılmıştır. PV-T kollektör yüzeyinden alınan 1S1, 1sı pompasına girdi olarak verilmiş ve aynı zamanda 1sı pompası sisteminin çalışması için gerekli olan iş fotovoltaik kollektörden sağlanmıştır. Jeolojik yapının el vermediği ve elektrik hatlarının ulaştırılamadığı bölgelerde tasarlanması için bu sistem ele alınmıştır.

PV-T destekli 1s1 pompası sistemindeki her bir eleman için enerji ve ekserji analizleri EES (Engineering Equation Solver) programı yardımıyla yapılmıştır. Isı pompasının çalıștırılması için gerekli elektriksel güç 9 adet PV-T kollektörden sağlanmıştır. Ayrıca 1sı pompası için gerekli olan 1sıl enerjide bu 9 adet PV-T kollektörü yüzeyinden su ile dolaşım sağlanarak 1sı pompasına aktarılması gerçekleştirilmiştir. Kullanılan PV-T hibrit sistemde toplam elektriksel güç $1422 \mathrm{~W}$, toplam alınan ısıl güçte 4397 W'dır. 
PV-T kollektörün 1sıl verimi 49.7, elektrik verimi 15.2 olarak hesaplanmıştır. PV-T kaynaklı 1Sı pompası sistemine kollektörlerin dahil edilmeden önceki verim değerine, uygulandıktan sonraki verim değerine katkısı \% 67.9 olarak görülmüştür. Işınım şiddeti arttıkça toplam elektriksel gücün ve toplam alınan 1sıl gücün arttığı görülmüştür. Ayrıca ortam sıcaklığına göre elektriksel verim ve 1 sıl verimin değişimi incelenmiş ortam sıcaklığı arttıkça elektriksel verimin düştüğü, 1sıl verimin arttığ1 görülmüştür. Yapılan bu çalışmada 1sı pompası sisteminin COP si 4.41 olarak hesaplanmıştır. En yüksek ekserji yıkımının kondenserde olduğu görülmüştür. Isıtma amaçlı yapılan PV-T destekli 1sı pompası sisteminde 1sıl güç olarak toplam $4686 \mathrm{~W}$ radyatör 1sıl gücü alınmıştır. Ayrıca, literatürde belirtilen benzer çalışmalarla ilgili karşılaştırmalarda, ortak ve yakın değerler yapılan analizlerde görülmüştür.

\section{Çıkar çatışması}

Yazarlar çıkar çatışması olmadığını beyan etmektedir.

\section{Benzerlik oranı (iThenticate): $\% 15$}

\section{Kaynaklar}

[1] M. Ö. Ültanır, 21. Yüzyılın eşiğinde güneş enerjisi. Bilim ve Teknik, 340, 50-55, 1996

[2] Z. Şen, Temiz Enerji ve Kaynakları, Su Vakfi Yayınları, İstanbul, 2002

[3] Enerji İşleri Genel Müdürlüğü, Güneş enerjisi ve teknolojileri, www.yegm.gov.tr/yenilenebilir/g_enj_ tekno.aspx Erişim Tarihi: 09.12.2019.

[4] J. Yao, H. Xu, Y. Dai and M. Huang, Performance analysis of solar assisted heat pump coupled with build in PCM heat storage based on PV/T panel. Solar Energy, 197, 279-291, 2020. https://doi.org/10.1016/ j.solener.2020.01.002

[5] A. N. Ozakin, K. Yakut and M. N. Khalaji, Performance analysis of photovoltaic-heat pump (PV/T) combined systems: A comparative numerical study. Journal of Solar Energy Engineering, 142, 2, 021010, 2020. https://doi.org/10.1115/1.4045313

[6] J. Ji, H. He, T. Chow, G. Pei, G. He, W. He and K. Liu, Distributed dynamic modelling and experimental study of PV evaporator in a PV/T solar-assisted heat pump. International Journal of Heat and Mass Transfer, 52, 1365-1373, 2009. https://doi.org/10.1016/j. ijheatmasstransfer.2008.08.017

[7] J. Ji, K. Liu, T. Chow, G. Pei, W. He and H. He, Performance analysis of a photovoltaic heat pump Applied Energy, 85, 680-693, 2008. https://doi.org/ 10.1016/j.apenergy.2008.01.003

[8] J. Ji, K. Liu, T. Chow, G. Pei and H. He, Thermal analysis of $\mathrm{PV} / \mathrm{T}$ evaporator of a solar-assisted heat pump. International Journal of Energy Research, 31, 525-545, 2007. https://doi.org/10.1002/er.1264

[9] H. D. Fu, G. Pei, J. Ji, H. Long, T. Zhang and T. T. Chow, Experimental study of a photovoltaic solarassisted heat pump/heat-pipe system. Applied Thermal Engineering, 40, 343-350, 2012. https://doi.org/ 10.1016/j.applthermaleng.2012.02.036
[10] R. Daghigh, M. H. Ruslan and K. Sopian, Advances in liqiuid based photovoltaic/thermal(PV/T) collectors. Renewable and Sustainable Energy Reviews. 15, 41564170, 2011. https://doi.org/10.1016/j.rser.2011.07.028

[11] V. V. Tyagi, S. C. Kaushik and S. K. Tyagi, Advancement in solar photovoltaic/thermal (PV/T) hybrid collector technology. Renewable and Sustainable Energy Reviews, 16, 1383-1398, 2012. https://doi.org/10.1016/j.rser.2011.12.013

[12] P. Zhang, X. Rong, X. Yang and D. Zhang, Design and performance simulation of a novel hybrid PV/T-air dual source heat pump system based on a three-fluid heat exchanger. Solar Energy, 191, 505-517, 2019. https://doi.org/10.1016/j.solener.2019.09.024

[13] N. Shao, L. Ma and J. Zhang, Experimental investigation on the performance of direct-expansion roof-PV/T heat pump system. Energy, 195, 116959, 2020. https://doi.org/10.1016/j.energy.2020.116959

[14] J. Zhou, Z. Zhu, X. Zhao, Y. Yuan, Y. Fan and S. Myers, Theoretical and experimental study of a novel solar indirect-expansion heat pump system employing mini channel PV/T and thermal panels. Renewable Energy, 151, 674-686, 2020. https://doi.org/ 10.1016/j.renene.2019.11.054

[15] J. Zhou, X. Ma, X. Zhao, Y. Yuan, M. Yu and J. Li, Numerical simulation and experimental validation of a micro-channel PV/T modules based direct-expansion solar heat pump system. Renewable Energy, 145, $1992-$ 2004, 2020. https://doi.org/10.1016/j.renene.2019. 07.049

[16] A. A. Ammar, K. Sopian, M. A. Alghoul, B. Elhub and A. M. Elbreki, Performance study on photovoltaic/ thermal solar-assisted heat pump system. Journal Thermal and Calorimetry, 136, 79-87, 2019. https://doi.org/10.1007/s10973-018-7741-6

[17] B. Evangelos and T. Christos, Multi-objective optimization of a solar assisted heat pump-driven by hybrid PV. Applied Thermal Engineering, 149, 528535, 2019. https://doi.org/10.1016/j.applthermaleng. 2018.12.059

[18] N. F. N. Razali, A. Fudholi, M. H. Ruslan and K. Sopian, Experiment study of water based photovoltaicthermal (PV/T) collector. International Journal of Electrical and Computer Engineering, 9(1), 118-125, 2019. http://doi.org/10.11591/ijece.v9i1.pp118-125

[19] S. C. Joe, Performance of a concentrating photovoltaic / thermal solar collector. Solar Energy, 78(2), 211-222, 2005. https://doi.org/10.1016/j.solener.2004.03.014

[20] Ö. Yamaç, Güneş enerjili destekli 1sı pompalarının teorik incelenmesi. Yüksek Lisans Tezi, Mustafa Kemal Üniversitesi Fen Bilimleri Enstitüsü, Hatay, Türkiye, 2005.

[21] F. Duran, PV/T Hibrit sistemlerin termodinamik ve performans analizi. Yüksek Lisans Tezi, Süleyman Demirel Üniversitesi Fen Bilimleri Enstitüsü, Isparta, Türkiye, 2014.

[22] A. Fudholi, K. Sopian, M. Yazd1, I. Ruslan and H. Kazem, Performance analysis of photovoltaic thermal (PVT) water collectors. Energy Conversion and 
Management, 78, 641-651, 2014. https://doi.org/ 10.1016/j.enconman.2013.11.017

[23] F. Benli, Fotovoltaik (PV) ve Fotovoltaik Termal (PVT) kolektörlerinin deneysel olarak karşılaştırılması. Yüksek Lisans Tezi, Osmaniye Korkut Ata Üniversitesi Fen Bilimleri Enstitüsü, Osmaniye, Türkiye, 2018.

[24] M. Caner, Yatay tüp topraklı isı pompası sisteminin Sivas şartlarında değerlendirilmesi. Yüksek Lisans Tezi, Cumhuriyet Üniversitesi Fen Bilimleri Enstitüsü, Sivas, Türkiye, 2018.

[25] M. Al-Khalıdı, Toprak kaynaklı 1sı pompası ile Isparta şartlarında bir ısıtma uygulaması. Süleyman Demirel Üniversitesi, Fen Bilimleri Enstitüsü, Isparta, Türkiye, 2018.

[26] F. Horzum, Bir turizm tesisinde toprak kaynaklı 1s1 pompası sisteminin termodinamik analizi. Yüksek
Lisans Tezi, Süleyman Demirel Üniversitesi, Fen Bilimleri Enstitüsü, Isparta, Türkiye, 2018.

[27] I. Dincer and M. A. Rosen, Exergy: Energy, Environment and Sustainable Development. Newnes, Oxford, UK, 2012.

[28] A. Bejan, G. Tsatsaronis and M. J. Moran, Thermal Design and Optimization. John Wiley and Sons, 1996.

[29] J. Szargut, D. R. Morris and F. R. Steward, Exergy Analysis of Thermal, Chemical, and Metallurgical Processes. Springer-Verlag, Berlin. 1987.

[30] J. A. Duffie and W. A. Beckman, Solar Engineering of Thermal Process. A Wiley-Interscience Publication, New York 2006.

[31] B. J. Huang, T. H. Lin, W. C. Hung and F. S. Sun, Performance evaluation of solar photovoltaic thermal systems. Solar Energy, 70(Feb), 443-448, 2001. https://doi.org/10.1016/S0038-092x(00)00153-5 